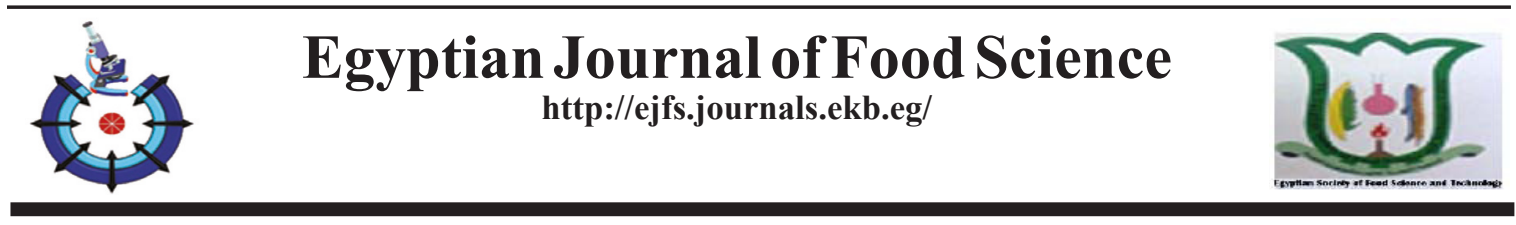

\title{
Impact of Purslane (Portulaca oleracea L.) Extract as Antioxidant and Antimicrobial Agent on Overall Quality and Shelf Life of Greek-Style Yoghurt
}

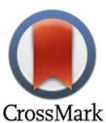

\author{
Mahmoud Ibrahim El-Sayed $^{1 *}$, Amel A. Ibrahim ${ }^{2}$ and Sameh Awad ${ }^{2}$ \\ ${ }^{1}$ Department of Dairy Technology Research, Food Technology Research Institute. \\ ARC, Giza, Egypt. \\ ${ }^{2}$ Laboratory of Dairy Microorganisms and Cheese Research (DMCR), Department of \\ Dairy Science and Technology, Faculty of Agriculture, Alexandria University, Egypt.
}

\begin{abstract}
$\mathbf{T}$ HIS study investigated the effect of purslane (Portulaca oleracea L.) leaves extract on Greek-style yogurt. Purslane extract showed higher antioxidant values and antimicrobial activity against Escherichia coli ATCC25922; Salmonella typhimurium ATCC14028. The fortified of Greek-style yoghurt with lyophilized purslane extract $2.2 \mathrm{~g} / \mathrm{L}(\mathrm{S} 1)$ and $4.4 \mathrm{~g} / \mathrm{L}$ (S2) significantly increased the antioxidant capacity. Greek-style yoghurt made with $4.4 \mathrm{~g} / \mathrm{L}$ lyophilized purslane extract received the highest antioxidant capacity and lowest sensory acceptability comparing with control and low dosage of lyophilized purslane extract.DPPH scavenging activity \% of S1 and S2 samples had no obvious change during storage period, while, FRAP values decreased in all treatments after 14 days of storage. The treatment of Greek-style yoghurt fortified with $2.2 \mathrm{~g} / \mathrm{L}$ lyophilized purslane extract was the most preference in sensory acceptability. This study recommended that the increasing of shelf life and antioxidant capacity and stability of all-natural Greek-style yoghurt, a dosage of lyophilized purslane extract $2.2 \mathrm{~g} / \mathrm{L}$ should be incorporated. Moreover, the P. oleracea could be used in functional foods as it has some bioactive components.
\end{abstract}

Keywords: Greek Yoghurt, Fermented milk, Purslane extract, Antibacterial activity, Antioxidants activity.

\section{Introduction}

Fermented milk is one of the most widespread foods that provide high nutritional value to consumers (Williams et al., 2015). Yoghurt is known as one of the most popular dairy products around the world with the consumption rate increasing over time. This product obtained from milk through the action of lactic acid bacteria (Nguyen et al., 2018). The popularity of yoghurt is due to its nutritional value and health benefits (Shah and Champagne, 2016) such as improved lactose tolerance and its physiological benefits such as antimicrobial and anticancer activity, activity against gastrointestinal infections, immune system stimulation and reduction in serum cholesterol (El-Abbadi et al., 2014; Chandan, 2015 and Shah et al., 2015). Concentrated yoghurt is consumed in large quantities in the Balkans and Middle East. Evidence of its production can be found in large number of countries such as Turkestan, the Balkans, the Eastern Mediterranean countries and the Indian Subcontinent (Tamime and Robinson, 2007). Greek-style yoghurt is a type of concentrated yoghurt, which possesses sensory attributes that are different from and nutritional properties that are superior to regular yoghurt (Nsabimana et al., 2005). The main

${ }^{*}$ Corresponding author : E-mail: mahmoud_im1981@yahoo.com

Received:19/4/2019; accepted:1/7/2019

DOI: 10.21608/EJFS.2019.12089.1005

(C)2019 National Information and Documentation Centre (NIDOC) 
characteristic of Greek yoghurts is texture, which is more consistent and creamier when compared to the traditional yoghurt (Uduwerella et al. 2018). Generally, for produce Greek yoghurt with this desired texture, different methods can be used, including concentration of ingredients that will be used in manufacturing by membrane technology (super filtration); concentration of components after fermentation step by centrifugation or desorption ; the direct addition of proteins (skim milk powder or milk protein concentrate) and stabilizers before fermentation (Desai et al., 2013; Uduwerella et al., 2018). The incorporation of prebiotic components into Greek yoghurts can lead to changes in the rheological properties of the final product (Pimentel et al., 2015). In recent study, galactooligosaccharide, polydextrose, and inulin were used in the manufacture of prebiotic Greek yoghurts (Costa et al., 2019), these ingredients provided a greater consistency, viscosity and elasticity, additionally, diversification of volatile compounds, with the formation of compounds that contribute to the sweet aroma, sweet taste, and buttery flavor. Nowadays, several studies have focused on improving the quality of fermented milk to enhance the consumer interest and health benefits of final products. Some studies used herbal extracts such as clove, lemongrass (Ramos et al., 2017), cinnamon (Helal and Tagliazucchi, 2018), garlic, onion and citrus (Michael et al., 2015) and stevia (Carvalho et al., 2018), not only to increase the bioactive compounds and antioxidant activity of fermented milks, but also to increases considerably the sensory acceptance of these new functional dairy foods. Another study by Mercan et al. (2018) showed that the yoghurts containing grape seed oil (GSO) exhibited significantly higher total phenolic content and radical scavenging activity as compared to control yoghurts. Kycia et al. (2018) found that the addition of $2 \%$ pullulan largely improved product stability by increasing gel firmness and adhesiveness.Purslane (Portulaca oleracea L.) is an annual green herb with stems and leaves that are fresh and edible, and a slightly acidic taste similar to spinach taste (Rashed et al., 2003). Erkan (2012) suggested that Portulaca oleracea could be used to produce functional foods such as functional dairy products as a raw material at lower costs. Purslane has a higher nutritive value than other vegetables, due to its content of $\alpha$-tocopherol, ascorbic acid, omega-3 fatty acid, $\beta$-carotene and glutathione (Wenzel et al., 1990). Purslane (P. oleracea) has been reported to possess antioxidant, anticancer, anti-inflammatory, hypochloresterolemic and bronchodilator (Masoodi et al., 2011). Phenolic alkaloids (oleracein A, B and E) of P. oleracea were showed antioxidant activity such as scavenging activity against 1,1-diphenyl- 2-picryl-hydrazyl (DPPH) radical and inhibitory effect on hydrogen peroxideinduced lipid peroxidation in homogenates of rat brain (Yang et al., 2009). The objective of this study was to investigate the antioxidant and antimicrobial properties of purslane extracts and evaluate the physicochemical, textural, microbiological, antioxidant and sensory properties of the Greek style yoghurts fortified with purslane extract during 21 days of storage at $4^{\circ} \mathrm{C}$.

\section{Materials and Methods}

\section{Samples}

Samples of purslane (Portulaca oleracea L.) were collected from Beheira Governorate in northern Egypt during September and October 2016. Purslane leaves were cut into bits and dried in an oven at $45^{\circ} \mathrm{C}$ for 3 days, then ground into a fine powder in a grinder, then packaged in vacuum plastic containers, then stored in a dark place at $4^{\circ} \mathrm{C}$ until extraction.

\section{Materials}

Buffalo milk (4.5\% protein and $7.0 \%$ fat) was obtained from the farm at Faculty of Agriculture, Alexandria, Egypt. Fresh pasteurized cream (50\% fat) was obtained from local markets, Alexandria. Cow skim milk powder (34\% protein) and milk protein concentrate $(70 \%$ protein) were obtained from Fonterra Ltd, Auckland, New Zealand. Folin-Ciocalteu reagent, Gallic acid, Ascorbic acid, Sodium nitrite, Aluminum chloride, Ferric chloride and Potassium ferricyanide were obtained from LobaChemie, Mumbai, India.1,1diphenyl-2-picryl-hydrazyl (DPPH) were from Sigma-Aldrich (Munich, Germany).

\section{Preparation purslane extracts}

Purslane leaves powders were extracted by cold distilled water $\left(25^{\circ} \mathrm{C}\right)$, ethanol $80 \%(\mathrm{v} / \mathrm{v})$ (Basirati et al. 2015) and hot distilled water $\left(90^{\circ} \mathrm{C}\right)$ (Gülcin et al. 2004). Extraction was carried out using $10 \%$ of leaves powder and stirring for 1 hour and then, the three extracts were filtrated through filter paper (Whatman no. 1). The ethanol extract was evaporated at $40{ }^{\circ} \mathrm{C}$ using rotary evaporator (HAHNVAPOR model HS-2005S), and then three extracts were freeze-dried (VirTis SP Scientific Sentry 2.0). Each 0.5 g lyophilized extract was 
diluted with $3.3 \mathrm{ml}$ dimethylsulfoxide (DMSO) $0.1 \%$ for the antibacterial activity test. For other tests, the lyophilized extracts $(0.5 \mathrm{~g})$ were dissolved in distilled water $(3.3 \mathrm{ml})$. The final concentration of used extract was $150 \mathrm{mg} / \mathrm{ml}$.

\section{Antibacterial activity of purslane extracts}

Agar well diffusion method

Agar well diffusion method was used to determine the antibacterial activity of purslane extracts against Salmonella typhimurium ATCC14028; Staphylococcus aureus ATCC6538; Escherichia coli ATCC25922 and Bacillus cereus, it was isolated from spoilage UHT milk and identified as $B$. cereus using $16 \mathrm{~S}$ rRNA sequencing. Each strain was incubated at its optimum temperature $/ 24 \mathrm{hr}$. The previous strains were optimized at concentration of $10^{8} \mathrm{CFU} /$ $\mathrm{ml}$, after that inoculated with 100, 200 and 300 $\mu 1$ separately to specific culture media S110 Agar (biolife, Italy) for S. aureus; Violet Red Bile Glucose Agar, (oxide, England) for E. coli and Salmonella typhimurium; Nutrient agar, (oxide,England) for Bacillus cereus and poured in a Petri dish. The wells (9 $\mathrm{mm}$ in diameter) were performed. Three different volumes $(100 \mu \mathrm{L}, 200$ $\mu \mathrm{L}$ or $300 \mu \mathrm{L})$ of each extract $(150 \mathrm{mg} / \mathrm{ml})$ was separately added to the wells and then incubated for $24 \mathrm{hr}$ at the optimum temperature of each strain. $100 \mu \mathrm{l}$ of each antibiotic (levofloxacin $(250$ $\mathrm{mg}$ ), Ampiflux (25 mg/ml), clindamycin (150 mg/ $\mathrm{ml})$ and Tetracycline $(250 \mathrm{mg} / \mathrm{ml})$ were used as positive control for Salmonella typhimurium; $E$. coli; S. aureus and B. cereus, respectively. The effect of solvent control DMSO $(0.1 \%)$ on the growth of microorganisms was also carried out. The presence of inhibition zone was regarded as the antimicrobial action. The average diameter of the inhibition zone was measured in millimeter.

\section{Microdilution method}

The antimicrobial activity was determined as minimum inhibitory concentration (MIC) using the microdilution method as an indicator of microbial growth (Sarker et al. 2007). All tests were done in duplicate and MIC value was recorded.

Determination of total phenolic in purslane and Greek yoghurt

Total phenolic contents of purslane and Greek yoghurt extracts were determined using the method developed by Abirami et al. (2014). One and half milliliters of Folin-Ciocalteu's reagent (diluted 10 times) and $1.2 \mathrm{ml}$ of $\mathrm{Na}_{2} \mathrm{CO}_{3}(7.5 \% \mathrm{w} / \mathrm{v})$ were added to $300 \mu \mathrm{l}$ of plant extract. Mixtures were shaken and kept at room temperature for $30 \mathrm{~min}$ before measuring absorbance at $765 \mathrm{~nm}$ using a spectrophotometer (Pg T80+, England), tests were carried out in triplicate. Total phenol content (TPC) was expressed as Gallic acid equivalent in $\mathrm{mg} / \mathrm{g}$ plant material or extract.

\section{Determination of total flavonoids}

The total flavonoids content of purslane and Greek yoghurt were determined according to Barros et al. (2011).Shortly, $0.5 \mathrm{ml}$ of purslane extract was mixed with $2 \mathrm{ml}$ of distilled water followed by addition of $150 \mu \mathrm{l}$ of $\mathrm{NaNO}_{2}(5 \%)$ solution. After $6 \mathrm{~min}, 150 \mu \mathrm{l}$ of $\mathrm{AlCl}_{3}(10 \% \mathrm{w} / \mathrm{v})$ was added and allowed to stand for another 6 min before $2 \mathrm{ml}$ of $\mathrm{NaOH}(4 \% \mathrm{w} / \mathrm{v})$ was added. The mixture was brought to $5 \mathrm{ml}$ with distilled water. Then the mixture was allowed to stand for $15 \mathrm{~min}$ at room temperature. The absorbance was measured at $510 \mathrm{~nm}$ using a spectrophotometer (Pg T80+, England). A calibration curve of Rutin was prepared and total flavonoids content was determined.

\section{Determination of antioxidant activity}

DPPH scavenging activity\%

Scavenging activity of the stable 1,1-diphenyl2-picrylhydrazyl (DPPH) radical was determined according to the procedure based on BrandWilliams et al. (1995). Two milliliters of $0.15 \mathrm{mM}$ DPPH were added to $1 \mathrm{ml}$ of extracts in different dilutions. A control was prepared by adding $2 \mathrm{ml}$ of DPPH to $1 \mathrm{ml}$ of methanol. The contents of the tubes were mixed and allowed to stand for $30 \mathrm{~min}$, and absorbance was measured at $517 \mathrm{~nm}$ using a spectrophotometer (Pg T80+, England). Triplicate tubes were prepared for each extract. The results were expressed as \% radical scavenging activity.

Radical scavenging activity $\%=\frac{(\text { A control }- \text { A sample })}{\text { Acontrol }} \times 100$

The $\mathrm{IC}_{50}$ which denotes the amount (mg) of the plant extract in $1 \mathrm{ml}$ solution required to reduce initial concentration of DPPH radicals by $50 \%$ was also calculated. Ascorbic acid was used as a standard.

\section{Ferric reducing antioxidant power (FRAP)}

Ferric reducing antioxidant power was determined according to Oyaizu (1986). One milliliter of extracts in different dilutions was added to $2.5 \mathrm{ml}$ phosphate buffer $(0.1 \mathrm{M}$, pH 6.6) 
and $2.5 \mathrm{ml}$ potassium ferricyanide $(1 \% \mathrm{w} / \mathrm{v})$. The mixture was then incubated in a water bath at $50^{\circ} \mathrm{C}$ for $20 \mathrm{~min}$ followed by $2.5 \mathrm{ml}$ trichloroacetic acid $(10 \% \mathrm{w} / \mathrm{v})$ solution. The contents of the tubes were mixed well and $2.5 \mathrm{ml}$ of solution was removed from each tube. To this, $2.5 \mathrm{ml}$ solution, $2.5 \mathrm{ml}$ water and $0.5 \mathrm{ml}$ ferric chloride solution $(0.1 \%$ $\mathrm{w} / \mathrm{v})$ were added. The mixtures were allowed to stand for $30 \mathrm{~min}$ before absorbance measurements at $700 \mathrm{~nm}$ using a spectrophotometer (Pg T80+, England). Triplicate tubes were prepared for each extract. The FRAP values, expressed in $\mathrm{mg}$ $\mathrm{GAE} / \mathrm{g}$, were derived from a standard curve.

\section{Greek-style yoghurt preparation}

Greek style yoghurt was manufactured from mixture of full fat buffalo milk (50\%), skimmed milk powder $(5 \%)$, milk protein concentrate $(2.5 \%)$ and cream $(12.5 \%)$. Three treatments of Greek yoghurt were made; $\mathrm{C}$, control; S1, adding lyophilized cold water extract of purslane at 2.2 $\mathrm{g} / \mathrm{L}$ and S2, adding lyophilized cold water extract of purslane at $4.4 \mathrm{~g} / \mathrm{L}$. The mixtures were heated at $90{ }^{\circ} \mathrm{C}$ for $10 \mathrm{~min}$ then cooling to $40{ }^{\circ} \mathrm{C}$. Then, YOFLEX ${ }^{\circledR}$ commercial yogurt starter culture (Streptococcus thermophilus and Lactobacillus delbrueckii ssp. bulgaricus were obtained from Chr. Hansen, (Hoersholm, Danmark)) was directly inoculated at dosage recommended by supplier. The incubation was at $42^{\circ} \mathrm{C}$ until the $\mathrm{pH}$ value reached 4.6. After that, the Greek yoghurt samples were cooled overnight in refrigerator, mix well and packaged in polyethylene cups. The samples were stored at $4^{\circ} \mathrm{C}$ and evaluated during the storage period $(1,7,14$ and 21 days).

\section{Physicochemical analysis of yoghurt \\ Titratable acidity and $\mathrm{pH}$}

The $\mathrm{pH}$ of homogenized Greek-style yoghurts was measure dusing $\mathrm{pH}$ meter (Martini, Italy) (Kailasapathy 2006). The titratable acidity (TA) of yoghurt was determined by titrating the samples with a $0.01 \mathrm{~N} \mathrm{NaOH}$ solution, and its value was expressed as lactic acid (\%) (Barkallah et al., 2017).

\section{Chemical composition}

Chemical compositions of Greek-style yoghurt samples (protein, fat and total solids) were measured using the AOAC procedures (AOAC, 2005).

Preparation of Greek-style yoghurt water extracts

Yoghurt samples (10 g) were homogenized with $2.5 \mathrm{ml}$ distilled water and then acidified to $\mathrm{pH} 4.0$ with $\mathrm{HCl}(0.1 N)$ followed by heating at
$45{ }^{\circ} \mathrm{C}$ for $10 \mathrm{~min}$ in water bath and centrifuged at $4500 \mathrm{xg}$ for $10 \mathrm{~min}$ at $4^{\circ} \mathrm{C}$. The $\mathrm{pH}$ of the supernatants was adjusted to $\mathrm{pH} 7.0$ using $\mathrm{NaOH}$ $(0.1 \mathrm{~N})$ and re-centrifuged $(4500 \mathrm{xg}, 10 \mathrm{~min} / 4$ ${ }^{\circ} \mathrm{C}$ ) for further precipitation of proteins and the supernatant was collected and stored in a $-20{ }^{\circ} \mathrm{C}$ until analysis (Shori and Baba, 2013).

\section{Determination of viscosity}

The viscosity of Greek-style yoghurt samples that stored at $10{ }^{\circ} \mathrm{C}$ overnight was measured using oscillatory viscometer (VR 3000M YR Viscometers, Spain), using spindle L3 at speed of $60 \mathrm{rpm}$.

\section{Texture profile analysis}

The texture characterization of Greek-style yoghurt was evaluated by back extrusion (Stable Micro Systems Ltd., Godalming, UK) with $35 \mathrm{~mm}$ disc. The speed was $1 \mathrm{~mm} / \mathrm{s}$, distance target was $30 \mathrm{~mm}$ and the trigger was $10 \mathrm{~g}$. The firmness, adhesiveness, and consistency values for all samples were measured at $0,7,14$ and 28 days based on the method of Nguyen et al. (2017). The results were given as the mean of three measurements.

\section{Microbiological quality of Greek yoghurt}

Coliform enumeration of the samples during storage time were according to ISO 4832: 2006. Yeast and molds were enumerated on Dichloran Rose-Bengal Chloramphenicol (DRBC) agar medium (Oxoid, England). Plates were incubated at $25^{\circ} \mathrm{C}$ for 5 days (ISO 21527-1:2008).

\section{Sensory evaluation}

Greek-style yoghurt samples were evaluated during storage period (1, 7, 14 and 21 days) for organoleptic characteristics (color, flavor, texture, appearance and overall acceptability) by 10 trained panelists ( 6 males and 4 females) from the Department of Dairy Science and Technology, Faculty of Agriculture, Alexandria University, with ages ranging from 26 to 50 years, they have a good experience in the sensory evaluation of dairy products.Greek yoghurt samples $(40 \mathrm{~g})$ were presented in white plastic cups coded randomly with 3-digit numbers, at a temperature of $20^{\circ} \mathrm{C}$. Water was provided between evaluations of samples for mouth rinsing. Ten points system was used for evaluation based on the method of Gould (1977) with minor modification. Sensory evaluation scores: excellent $=10$; very $\operatorname{good}=8$; $\operatorname{good}=6$; accept $=4$; reject $=2$. 


\section{Statistical analysis}

The data were analyzed by a general linear model procedure of the Fisher's protected leastsignificant difference (PLSD) test using SAS, 2004 (SAS Institute, Inc., Cary, NC). This test combines ANOVA with a comparison of differences between the means of the treatments at the significance level of $\mathrm{P} \leq 0.05$. Correlations were calculated using Pearson's correlation coefficient.

\section{Results and Discussion}

Antibacterial activity of purslane extracts

The results of antibacterial activity of purslane extracts showed that the extracts have antibacterial activity against Escherichia coli ATCC 25922; Salmonella typhimurium ATCC 14028 , but there was no any effect against Staphylococcus aureus ATCC 6538 and Bacillus cereus (Table 1). The reason for different sensitivity between Gram-positive and Gram-negative bacteria may refer to cell wall morphological differences between these microorganisms. Ethanol, cold and hot water extracts $(300 \mu l)$ exhibited an inhibition zone with diameter of 26, 26 and 25 mm respectively with E.coli. A similar report was observed by Peng et al. (2014). The cold extract $(100 \mu \mathrm{l})$ had a greater inhibiting effect than the hot water against E.coli. This result in agreement with results of Udu-Ibiam et al. (2014). Cold and hot water extracts showed antibacterial activity against Salmonella typhimurium only at high doses $(300 \mu 1)$; meanwhile, ethanol extract showed inhibition activity at $200 \mu \mathrm{l}$ and $300 \mu \mathrm{l}$. The inhibition zones of all extracts against Salmonella typhimurium were ranged from 14-18 $\mathrm{mm}$. Ethanol extract exhibit the best antibacterial activity against E. coli and Salmonella typhimurium. The inhibition zones of all extracts were concentrated-dependent. The MIC value of ethanol $80 \%$ extract was $12.5 \mathrm{mg} / \mathrm{ml}$ against $E$. coli followed by a cold water extract, $37.5 \mathrm{mg} / \mathrm{ml}$ (Table 2). The ethanol extract showed the lowest MIC (25 mg/ml) against Salmonella typhimurium. There were no differences between cold and hot water extracts $(75 \mathrm{mg} / \mathrm{ml})$. MIC value of coldwater extract against Staphylococcus aureus was $300 \mathrm{mg} / \mathrm{ml}$, while it was $150 \mathrm{mg} / \mathrm{ml}$ with ethanol extract. Bacillus cereus was the most resistant to purslane extracts. The antimicrobial activity of purslane related to the phenolic component, extracts with high phenolic content showed a stronger antibacterial capacity (Abo El-Maati et al., 2015).

\section{Total phenolic and total flavonoids of Purslane extracts}

Total phenolic of ethanol extract was significantly $(\mathrm{P} \leq 0.05)$ higher than cold and hot water extracts, meanwhile no significant $(\mathrm{P} \geq 0.05)$ difference between cold and hot water extracts (Table 3). On the other side, the ethanol extract was the lowest in flavonoids content compared with cold and hot water extracts, and no significant $(\mathrm{P} \geq 0.05)$ difference between extractions by cold or hot water. Plants comprise a great diversity of compounds, including flavonoids (flavonols, flavones, anthocyanins, etc.) and non-flavonoids as phenolic compounds (phenolic acids, lignins, stilbenes, terpenoids, etc.). Uddin et al. (2012) found that the ethanol extract has higher phenolic contents than water extract. Cai et al. (2004) reported that the water extracts of $P$. oleracea at $80{ }^{\circ} \mathrm{C} / 20$ min yielded higher total phenol content $(0.6 \mathrm{~g} / 100 \mathrm{~g} \mathrm{DW})$ than methanol extracts $(0.4$ $\mathrm{g} / 100 \mathrm{~g} \mathrm{DW})$.

TABLE 1 . Antibacterial activity of extracts as inhibition diameter zone.

\begin{tabular}{ccccccc}
\hline & $\begin{array}{c}\text { Concentration } \\
\text { of extracts } \\
\text { Target strains }\end{array}$ & $\begin{array}{c}\text { Ethanol } \\
\text { extract }\end{array}$ & $\begin{array}{c}\text { Water } \\
\text { Extract } \\
\text { (hot) }\end{array}$ & $\begin{array}{c}\text { Water } \\
\text { extract } \\
\text { ( cold) }\end{array}$ & $\begin{array}{c}\text { Control (+) } \\
\mathbf{1 0 0} \\
\text { L } \boldsymbol{\mu}\end{array}$ & DMSO \\
\hline \multirow{2}{*}{ E. coli ATCC25922 } & 100 & $22 \mathrm{~mm}$ & $13 \mathrm{~mm}$ & $18 \mathrm{~mm}$ & & \\
Salmonella & 200 & $26 \mathrm{~mm}$ & $26 \mathrm{~mm}$ & $24 \mathrm{~mm}$ & $21 \mathrm{~mm}$ & $\mathbf{1 m m}$ \\
typhimurium & 300 & $26 \mathrm{~mm}$ & $26 \mathrm{~mm}$ & $25 \mathrm{~mm}$ & & \\
ATCC14028 & 100 & - & - & - & & - \\
S.aureus & 200 & $12 \mathrm{~mm}$ & $-\square$ & - & $27 \mathrm{~mm}$ & \\
ATTC6538 & 300 & $18 \mathrm{~mm}$ & $17 \mathrm{~mm}$ & $14 \mathrm{~mm}$ & & - \\
& 100 & - & - & - & & \\
B. cereus & 200 & - & - & - & $40 \mathrm{~mm}$ & \\
& 300 & - & - & - & & - \\
\hline
\end{tabular}


TABLE 2. Minimum inhibitory concentration of extracts against pathogenic bacteria.

\begin{tabular}{lccc}
\hline \multirow{2}{*}{ Tested bacteria } & \multicolumn{3}{c}{ MIC value ( mg/ml) } \\
\cline { 2 - 4 } & $\begin{array}{c}\text { Ethanol } \\
\mathbf{8 0 \%} \text { Extract }\end{array}$ & $\begin{array}{c}\text { Cold water } \\
\text { Extract }\end{array}$ & $\begin{array}{c}\text { Hot water } \\
\text { Extract }\end{array}$ \\
\hline B. cereus & - & - & - \\
E. coli & 12.5 & 37.5 & 150 \\
Staph. aureus & - & - & - \\
S. typhimurium & 25 & 75 & 75 \\
\hline
\end{tabular}

TABLE 3. Effect of extraction method on yield, DPPH inhibition (\%), IC50 (mg/ml), FRAP (mg GA/ g), T. Phenols ( $\mathrm{mg} \mathrm{GA} / \mathrm{g}$ ) and T. flavonoids $\mu \mathrm{g} / \mathrm{ml}$ of purslane extracts.

\begin{tabular}{lcccccc}
\hline \multicolumn{1}{c}{ Sample } & $\begin{array}{c}\text { Extract yield } \\
(\mathbf{g})\end{array}$ & $\begin{array}{c}\text { DPPH } \\
\text { inhibition } \\
\mathbf{( \% )}\end{array}$ & $\begin{array}{c}\text { IC50 } \\
(\mathbf{m g} / \mathbf{m l})\end{array}$ & $\begin{array}{c}\text { FRAP } \\
(\mathbf{m g ~ G A} / \mathbf{g})\end{array}$ & $\begin{array}{c}\text { T. Phenols } \\
(\mathbf{m g ~ G A} / \mathbf{g})\end{array}$ & $\begin{array}{c}\text { T. flavonoids } \\
\boldsymbol{\mu g} / \mathbf{m l}\end{array}$ \\
\hline Ethanolic extract & $1.24 \pm 0.07^{\mathrm{c}}$ & $92.45 \pm 0.44^{\mathrm{a}}$ & $1.70 \pm 0.01^{\mathrm{c}}$ & $0.72 \pm 0.00^{\mathrm{a}}$ & $21.06 \pm 0.20^{\mathrm{a}}$ & $221.5 \pm 7.5^{\mathrm{b}}$ \\
Cold water extract & $1.68 \pm 0.07^{\mathrm{a}}$ & $90.28 \pm 0.50^{\mathrm{b}}$ & $2.20 \pm 0.03^{\mathrm{b}}$ & $0.54 \pm 0.01^{\mathrm{b}}$ & $17.62 \pm 0.35^{\mathrm{b}}$ & $617.5 \pm 8.5^{\mathrm{a}}$ \\
Hot water extract & $1.52 \pm 0.06^{\mathrm{b}}$ & $88.41 \pm 0.30^{\mathrm{c}}$ & $2.35 \pm 0.03^{\mathrm{a}}$ & $0.45 \pm 0.01^{\mathrm{c}}$ & $16.97 \pm 0.23^{\mathrm{c}}$ & $627.5 \pm 14.0^{\mathrm{a}}$ \\
\hline
\end{tabular}

Values are mean $\pm \operatorname{SD}(n=3)$. The level of significant was present at $\mathrm{p}<0.05$.

Means in a column with commonupper case superscript letters are not different $(p>0.05)$.

Antioxidant activity of purslane extracts

The antioxidant activity of purslane extracts (ethanol, cold water and hot water extracts) was determined by DPPH and FRAP assays (Table 3). DPPH inhibition \% and FRAP were significant higher $(P \leq 0.05)$ in ethanol extract when compared with water extracts. These results may be due to the higher content of total phenolic in ethanol extract (Youssef and Mokhtar 2014). Total phenolic have a strong antioxidant activity and ability to scavenge free radicals (Li et al. 2006: Abo El-Maati et al. 2015).

Effect of purslane extract on titratable acidity and pH of Greek-style yoghurt

Greek-style yoghurt samples had the same behavior in titratable acidity (TA) and $\mathrm{pH}$ during storage (Table 4). The TA of yoghurt samples ranged from 1.17 to 1.40 . There are no significant differences $(P \geq 0.05)$ between all treatments at the first day of storage. While, at the day 7 and day 14, $\mathrm{S} 1$ samples showed a significant higher $(P \leq 0.05)$ in TA than S2 and control samples. TA was lower $(\mathrm{P} \leq 0.05)$ in $\mathrm{S} 2$ than $\mathrm{S} 1$ and control samples at all times of storage. By the end of the storage period, there were no significant differences $(P \geq 0.05)$ between $\mathrm{S} 1$ and control samples. The $\mathrm{pH}$ of all treatments continuously dropped $(\mathrm{P} \leq 0.05)$ during the storage period, this result was agreed with Tseng and Zhao (2013).

Egypt. J. Food. 47, No.1 (2019)
Chemical composition of Greek-style yoghurt

The obtained results showed that there were no significant $(P \geq 0.05)$ differences in TS $(23 \%)$, protein $(5.7 \%)$ and fat $(9 \%)$ of all treatments (Table 5), this is related to standardization of the components before fermentation. Greekstyle yoghurt, also known as strained yoghurt, concentrated yoghurt derived from yoghurt by draining a way part of its whey (Kilara and Chandan 2013). So, protein (5.7\%) and fat (9\%) were much higher in Greek style yoghurt when compare with regular yoghurt $(\approx 3 \%$ and $3.5 \%$ respectively).

Microbiological quality of Greek-style yoghurt

Mold, yeast and coliform bacteria were not detected in all Greek-style yoghurt samples during storage at $4{ }^{\circ} \mathrm{C}$ for 3 weeks. The absence of these microorganisms indicated that the obtained yoghurt was safe even after storageat $4{ }^{\circ} \mathrm{C}$ for 3 weeks.

Total phenolic and total flavonoids in Greek-style yoghurt

Total phenolic contents in Greek yoghurt were increased $(\mathrm{P} \leq 0.05)$ with increasing the level of adding the extract of purslane (Fig. 1). Total phenolic contents were increased after 1 week in all treatments, while there was a decline 
in phenolic level after 2 weeks with the control treatment. There was a significant $(\mathrm{P} \leq 0.05)$ increase in phenolic level with samples fortified with two levels of extract during 3 weeks of storage. This could be due to the presence of phenolic phytochemicals in purslane extract (Shetty et al. 2005). The total phenolic contents were significant $(\mathrm{P} \leq 0.05)$ increased after first week in all treatments and then decreased in control samples after $2^{\text {nd }}$ week of storage. The fortified with purslane extract protected of total phenolic during storage. Total flavonoids contents in Greek yoghurt were increased $(\mathrm{P} \leq 0.05)$ with increasing the level of adding the extract of purslane (Fig. 1). Total flavonoids were increased after first week of storage in all treatments and decreased after $2^{\text {nd }}$ week. The degradation of milk proteins during proteolytic activity of yoghurt bacteria resulting in the release of some phenolic compounds such as phenolic acids, flavonoids and isoflavonoids present in purslane extract attached to milk protein during manufacturing of yoghurt (McCue and Shetty, 2005).
Antioxidant activities of Greek-style yoghurt

The antioxidant activity of Greek style yoghurt as determination by DPPH scavenging activity \% assay showed the highest $(P \leq 0.05)$ values with in $\mathrm{S} 2$ samples while the control sample received the lowest values (Fig. 1). According to the present results, DPPH scavenging activity \% of S1 and S2 samples had no obvious change during storage period, while the DPPH scavenging activity $\%$ of control samples was decreased during the storage period.Purslane extract has led to increase and stable the DPPH inhibition activity \% in Greekstyle yoghurt during storage period. Concerning FRAP assay, the highest FRAP values were observed in samples with addition of purslane extracts (S1 and S2) (Fig. 1). The FRAP values were decreased in all treatments after 14 days of storage; this was also reported by Vital et al. (2015). The obtained results confirmed that the purslane extract increased the values and stability of antioxidant activity in Greek-style yoghurt. The fermentation of milk results in

TABLE 4. Effect of purslane extract on total titratable acid in Greek yoghurt during 21 days of storage at $4{ }^{\circ} \mathrm{C}$.

\begin{tabular}{cccc}
\hline Sample & Time (day) & Acidity & pH \\
\hline \multirow{3}{*}{ Control } & 1 & $1.17 \pm 0.01^{\mathrm{cA}}$ & $4.54 \pm 0.00^{\mathrm{aB}}$ \\
& 7 & $1.37 \pm 0.00^{\mathrm{bB}}$ & $4.36 \pm 0.00^{\mathrm{bB}}$ \\
& 14 & $1.39 \pm 0.00^{\mathrm{aB}}$ & $4.20 \pm 0.00^{\mathrm{cC}}$ \\
& 21 & $1.40 \pm 0.01^{\mathrm{aA}}$ & $4.14 \pm 0.00^{\mathrm{dC}}$ \\
& 1 & $1.16 \pm 0.02^{\mathrm{bA}}$ & $4.60 \pm 0.00^{\mathrm{aA}}$ \\
S1 & 7 & $1.39 \pm 0.00^{\mathrm{aA}}$ & $4.49 \pm 0.00^{\mathrm{bA}}$ \\
& 14 & $1.41 \pm 0.00^{\mathrm{aA}}$ & $4.31 \pm 0.01^{\mathrm{cB}}$ \\
& 21 & $1.40 \pm 0.00^{\mathrm{aA}}$ & $4.26 \pm 0.00^{\mathrm{dB}}$ \\
& 1 & $1.17 \pm 0.00^{\mathrm{dA}}$ & $4.50 \pm 0.00^{\mathrm{aC}}$ \\
S2 & 7 & $1.19 \pm 0.00^{\mathrm{cC}}$ & $4.48 \pm 0.02^{\mathrm{aA}}$ \\
& 14 & $1.30 \pm 0.00^{\mathrm{bC}}$ & $4.33 \pm 0.00^{\mathrm{bA}}$ \\
& 21 & $1.34 \pm 0.00^{\mathrm{aB}}$ & $4.31 \pm 0.00^{\mathrm{bA}}$ \\
\hline
\end{tabular}

Values are mean $\pm \mathrm{SD}(\mathrm{n}=3)$. The level of significant was present at $\mathrm{p}<0.05$.

Means in a column with common upper case superscript capital letters are not different $(\mathrm{p}>0.05)$.

TABLE 5. Chemical composition of Greek-style yoghurt.

\begin{tabular}{ccccc}
\hline Samples & Moisture \% & T.S \% & Fat \% & Protein \% \\
\hline Control & $77.33^{\mathrm{a}} \pm 0.22$ & $22.66^{\mathrm{a}} \pm 0.22$ & $8.88 \mathrm{a} \pm 0.20$ & $5.79^{\mathrm{a}} \pm 0.09$ \\
S1 & $76.31^{\mathrm{a}} \pm 1.07$ & $23.68^{\mathrm{a}} \pm 1.07$ & $9.00^{\mathrm{a}} \pm 0.00$ & $5.71^{\mathrm{a}} \pm 0.09$ \\
S2 & $77.25^{\mathrm{a}} \pm 0.25$ & $22.75^{\mathrm{a}} \pm 0.25$ & $9.00^{\mathrm{a}} \pm 0.03$ & $5.75^{\mathrm{a}} \pm 0.09$ \\
\hline
\end{tabular}

Values are mean $\pm \mathrm{SD}(\mathrm{n}=3)$. Means in a column with common upper case superscript letters are not different $(\mathrm{p}>0.05)$. 
boosting the antioxidant effect in all treatments. The concentration required to obtain $50 \% \mathrm{DPPH}$ radical scavenging activity $\left(\mathrm{IC}_{50}\right)$ for the Greek yoghurt incorporated with purslane extract was $2 \mathrm{~g} / \mathrm{L}$. The impact of antioxidants on DPPH radical scavenging is considered to be due to their ability of hydrogen-donating. Some antioxidant activities of yoghurt and other fermented milks are related to bioactive peptides released during fermentation and also during storage periods, the bioactive peptide showed antioxidant activity in-vivo and in-vitro (ŞanlıdereAloğlu and Oner 2011; Awad et al. 2016). Also, the other bioactive compounds in milk, such as protein, fat, vitamins have good antioxidant activities. The DPPH radical scavenging rate was increased with the increasing concentration of exopolysaccharides (EPS) (Zhu et al. 2018). Moreover, You Guo et al. (2009) reported that purslane polysaccharides showed a good effect on scavenging of hydroxyl radicals, $\mathrm{DPPH}$, superoxide anion and nitric oxide in a dose-dependent manner. The decrease of FRAP after the second week,probably associated with the formation of a complex between polyphenols and milk proteins (Lamothe et al. 2014). Yazici et al. (2007) reported that the salinity tolerance of purslane might be related to the increasing of antioxidant capacity to scavenge more reactive oxygen species. The antioxidant activity which observed in this study may be attributed to the combined effect of bioactive compounds in purslane extract and the action of lactic acid bacteria (Papadimitriou et al., 2007).

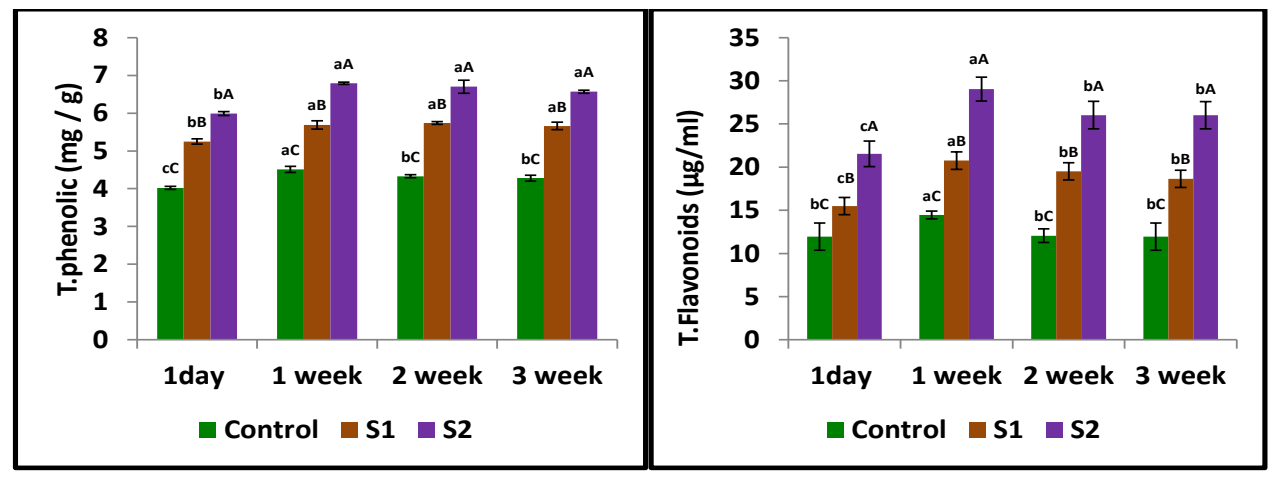

(a)

(b)

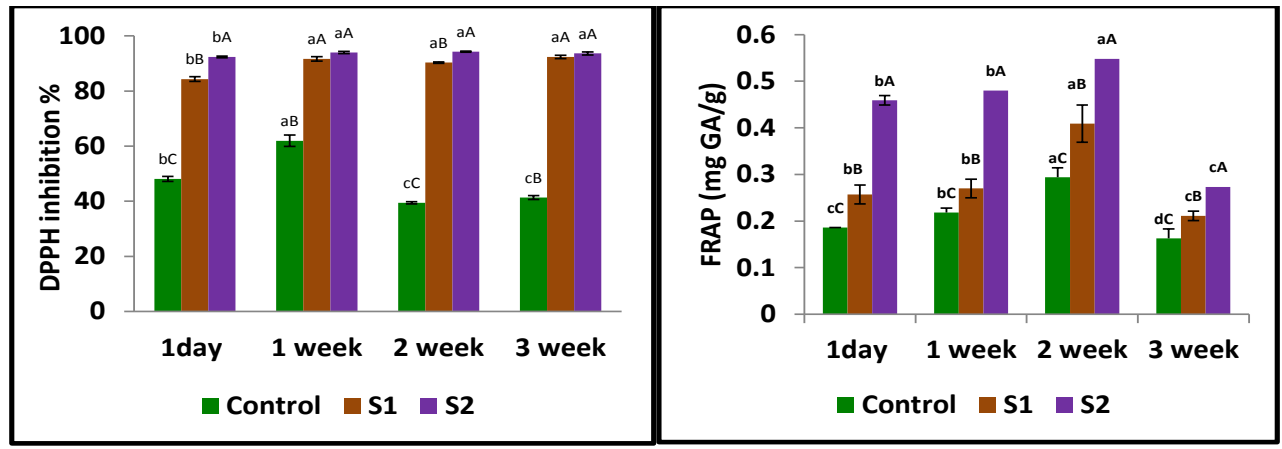

(c)

(d)

Fig.1. Effect of purslane extract on(a) total phenolic, (b) total flavonoids, (c) DPPH inhibition (\%), and (d) FRAP value, of Greek style yoghurt during 21 days of storage at $4^{\circ} \mathrm{C}$.

Values are mean $\pm \operatorname{SD}(n=3)$. The level of significant was present at $p<0.05$.

Means with common upper case superscript letters are not different $(\mathrm{p}>0.05)$

S1: Greek-style yoghurt fortified with lyophilized purslane extract $(2.2 \mathrm{~g} / \mathrm{L})$.

S2: Greek-style yoghurt fortified with lyophilized purslane extract $(4.4 \mathrm{~g} / \mathrm{L})$.

Egypt. J. Food. 47, No.1 (2019) 


\section{Texture and viscosity measurements}

The obtained results showed that the firmness, consistency, adhesiveness and viscosity values were higher $(P \leq 0.05)$ in control sample compared with treated samples by extracts at first day and during the storage period at $4^{\circ} \mathrm{C}$ (Fig. 2). The texture parameters and viscosity were increased during storage. Adding more extract dosage in yoghurt, reduced the viscosity values when compared with low dosage. The highest values of firmness were detected in the control sample $(\mathrm{P} \leq$ 0.05 ) at first day and during cold storage at $4^{\circ} \mathrm{C}$ and a decrease in firmness values were depending on the amount added of purslane extract. Öztürk et al. (2018) found that the firmness of yoghurt control samples was higher than that of yoghurt fortified with Elaeagnus angustifolia L. flours. The addition of purslane extract decreased the consistency of Greek-style yoghurt at first day when compared to control. This may be related to the concentration of polysaccharides in purslane extract.The higher polysaccharide concentrations may have resulted in the formation of polysaccharide-protein interactions that are weaker than protein-protein bonds (Ramchandran and Shah, 2009). Therefore, the consistency of S2 samples was lower than S1 samples. The consistency of all Greek yoghurts was increased during the cold storage period. Also, the adhesiveness values of fortified Greek yoghurt were lower $(\mathrm{P} \leq 0.05)$ than control. The adhesiveness of all treatments was increased at the end of storage compared to the first day.

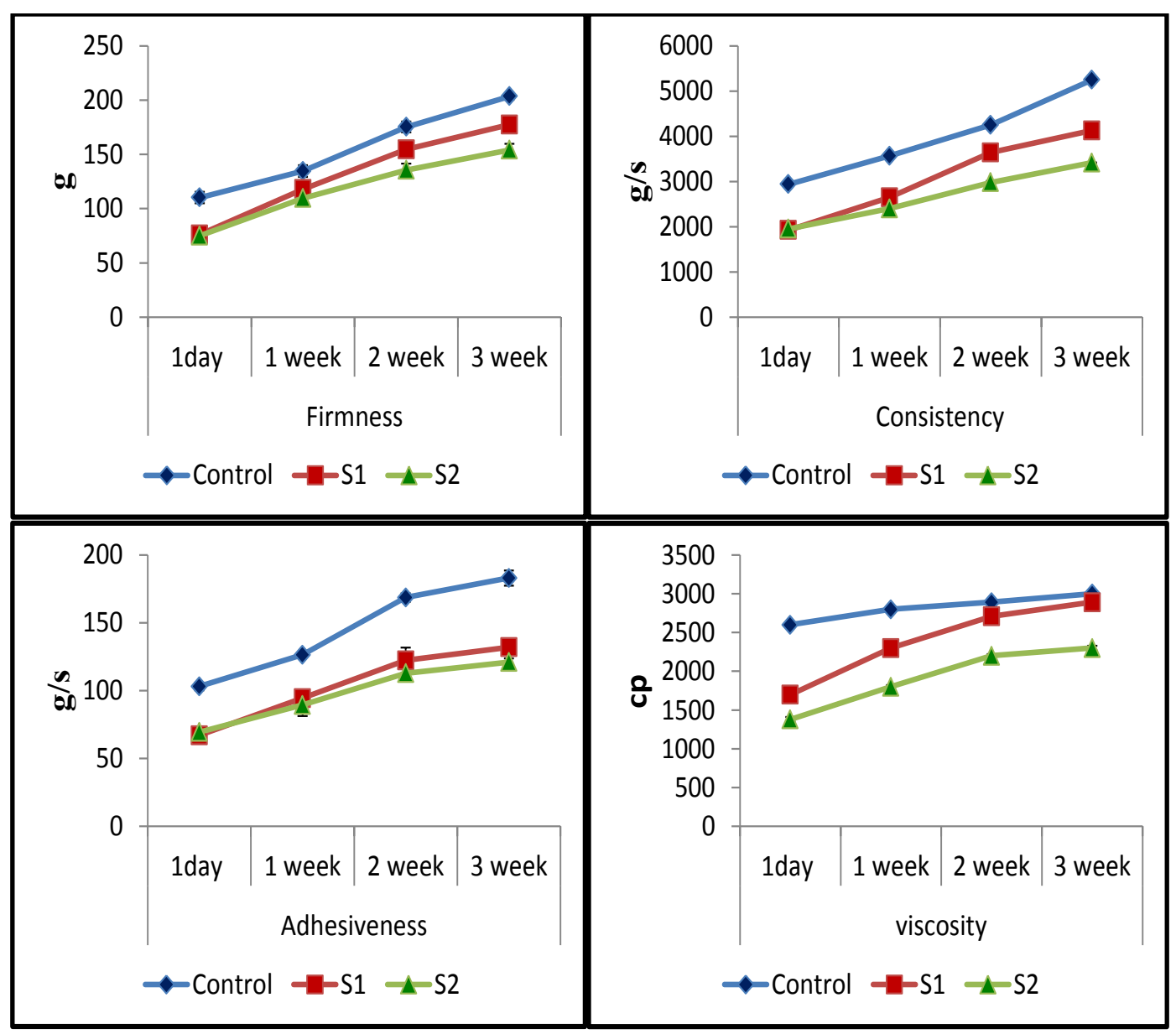

Fig. 2. Effect of purslane extract addition on texture analysis of Greek style yoghurt during 21 days of storage at $4^{\circ} \mathrm{C}$.

Values are mean $\pm \mathrm{SD}(\mathrm{n}=3)$. The level of significant was present at $\mathrm{p}<0.05$.

$\mathrm{S} 1$ : Greek-style yoghurt fortified with lyophilized purslane extract $(2.2 \mathrm{~g} / \mathrm{L})$.

$\mathrm{S} 2$ : Greek-style yoghurt fortified with lyophilized purslane extract $(4.4 \mathrm{~g} / \mathrm{L})$. 


\section{Sensory evaluation}

The sensory evaluation of individual Greek yoghurt samples for color, flavor, body and texture, appearance and overall acceptability showed that all treatments were accepted by panelists (Fig. 3). Fortification of Greek yoghurt by $2.2 \mathrm{~g} / \mathrm{L}$ lyophilized purslane extract (S1 treatment) improved the scores $(P \leq 0.05)$ of flavor, texture, appearance and overall acceptability during the first 14 days of storage comparing to control and S2 treatment $(4.4 \mathrm{~g} / \mathrm{L})$. But the color of fortified Greek yoghurt by lyophilized purslane extract received lower scores when compared to control. While, fortification of Greek yoghurt by $4.4 \mathrm{~g} / \mathrm{L}$ lyophilized purslane extract (S2 treatment) reduced the sensory acceptability. Storage time has asignificant $(P \leq 0.05)$ negative effect on sensory properties of all treatments, and the reduction in acceptability was more pronouncing with both fortified treatments. Consumers demand preferred foods with health benefits (Thompson et al., 2007). Yoghurt is a conventional food known for its therapeutic, nutritional and sensory properties (Hekmat et al., 2009). In respect to color, flavor, body and texture, and appearance, all Greek-style yoghurt products received scores above 5 in the ten points hedonic scale, which indicates consumers liked the products with purslane extract.
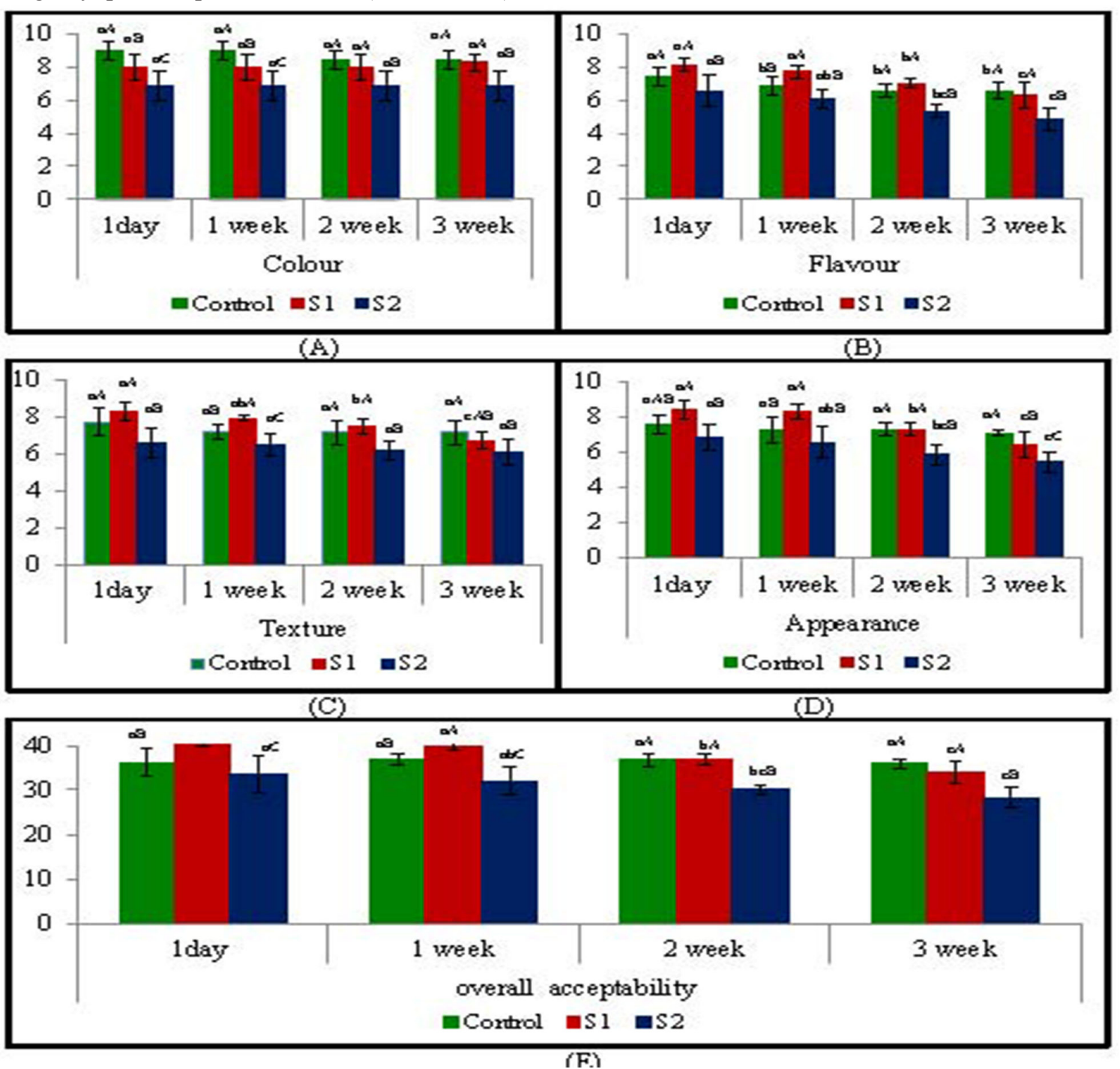

Fig. 3. Sensory evaluation of Greek style yoghurt during 21 days of storage at $4^{\circ} \mathrm{C}$.

Values are mean $\pm \operatorname{SD}(\mathrm{n}=10)$. The level of significant was present at $\mathrm{p}<0.05$.

Means with common upper case superscript letters are not different $(\mathrm{p}>0.05)$.

$\mathrm{S} 1$ : Greek-style yoghurt fortified with lyophilized purslane extract $(2.2 \mathrm{~g} / \mathrm{L})$.

$\mathrm{S} 2$ : Greek-style yoghurt fortified with lyophilized purslane extract $(4.4 \mathrm{~g} / \mathrm{L})$.

Egypt. J. Food. 47, No.1 (2019) 


\section{Conclusion}

From above comparative results and discussion, it could be concluded that the purslane extracts exhibit high antimicrobial activity against Gram negative bacteria such as E. coli and Salmonella typhimurium, and low antimicrobial activity against Gram positive bacteria such as Staphylococcus aureus and Bacillus cereus. As well as, the purslane extracts exhibit high antioxidant activities, the fortification of Geek-style yoghurt with lyophilized purslane extract $2.2 \mathrm{~g} / \mathrm{L}$ and $4.4 \mathrm{~g} / \mathrm{L}$ significantly increased the antioxidant capacity and increased the stability of antioxidant behavior during storage. The Geek-style yoghurt made with lyophilized purslane extract $2.2 \mathrm{~g} / \mathrm{L}$ received high scores of sensory properties. This study recommended the fortification of yoghurt with dosage of lyophilized purslane extract $2.2 \mathrm{~g} / \mathrm{L}$ enhanced the antioxidant activity and stability of all-natural functional products. The P. oleracea could be used in functional foods as it has some bioactive components, as well as the plant is produced in the entire world with low cost. So, it could be used by food industries for function food production.

\section{Acknowledgments}

The authors thank Prof. Sobhy El Sohaimy and Dr. Amira Darwish, City of Scientific Research and Technological Applications, Egypt for helpingin lyophilize of extracts. Also, we would like to thank Prof.Hassan Zaky, Desert Research Center, Egypt, for helping in statistical analysis.

\section{References}

Abirami, A., Nagarani, G., and Siddhuraju, P. (2014) In vitro antioxidant, antidiabetic, cholinesterase andtyrosinase inhibitory potential of fresh juice from Citrus hystrix and C. maxima fruits. Food Science and Human Wellness, 3, 16-25.

Abo El-Maati, M.F., Mahgoub, S. A., Labib, S.M., Al-Gaby, A.M.A., and Ramadan M F. (2015) Phenolic extracts of clove (Syzygiumaromaticum) with novel antioxidant and antibacterial activities. European Journal of Integrative Medicine, 8 (4), 494-504.

AOAC. (2005) Official Methods of Analysis of AOAC International. (18 $8^{\text {th }}$ ed.) Gaithersburg.

Awad S., El-Sayed M. I., Wahba A., El Attar A., Yousef M. I. and Zedan M. (2016) Antioxidant activity of milk protein hydrolysate in alloxan-induced diabetic rats. Journal Dairy Science, 99, 8499 8510 .

Barkallah, M., Dammak, M., Louati, I., Hentati, F., Hadrich, B., Mechichi, T., Ayadi, M.A., Fendri, I., Attia H., and Abdelkafi, S. (2017) Effect of Spirulinaplatensis fortification on physicochemical, textural, antioxidant and sensory properties of yogurt during fermentation and storage. LWT Food Science and Technology, 84, 323-330.

Barros, L., Cabrita, L, Boas, M. V., Carvalho, A. M. and Ferreira, I.C.F.R. (2011) Chemical, biochemical and electrochemical assays to evaluate phytochemicals and antioxidant activity of wild plants. Food Chemistry, 127, 1600-1608.

Basirati, Z., Torabi, S., Ebrahimi, M. T. (2015) Effect of Ethanolic and Aqueous Extracts of Purslane on Probiotic Bacteria (Lactobacillus acidophilus and Lactobacillus casei). Journal of Applied Environmental and Biological Sciences, 4 (11S)146-149

Brand-Williams W, Cuvelier M E and Berset C (1995) Use of free radical method to evaluate antioxidant activity. LWT- Food Science and Technology, 28 (1), 25-30.

Cai, Y., Luo, Q., Sun, M. and Corke, H. (2004) antioxidant activity and phenolic compounds of 112 traditional Chinese medicinal plants associated with cancer. Life Sciences, 74 2157-2184.

Carvalho M W D, Arriola N D A, Pinto S S, Verruck S, Fritzen-Freire C B, Prudêncio E S and Amboni R D D M C (2018) Stevia-fortified yoghurt: Stability, antioxidant activity and in vitro digestion behavior. International Journal of Dairy Technology, 72 (1) 57-64.

Chandan, R. C. (2015) Health benefits of yogurt. In Health Benefits of Fermented Foods and Beverages, pp. 275-295.Tamang J P, Ed. CRC Press, Taylor and Francis, Boca Raton, FL, USA.

Costa, M. F., Pimentel, T. C., Guimaraes, J. T., Balthazar C. F., Rocha, R. S., Cavalcanti, R. N., Esmerino, E. A., Freitas, M. Q., Raices, R. S. L., Silva, M. C. and Cruz, A. G. (2019) Impact of prebiotics on the rheological characteristics and volatile compounds of Greek yogurt. LWT - Food Science and Technology, 105, 371-376.

Desai N T, Shepard L and Drake M A (2013) Sensory properties and drivers of liking for Greek yogurts. Journal of Dairy Science, 96, 7454-7466. 
El-Abbadi, N. H., Dao, M.C. and Meydani, S. N. (2014) Yogurt: role in healthy and active aging. The American Journal of Clinical Nutrition, 99 (5) 1263S-1270S.

Erkan, N. (2012) Antioxidant activity and phenolic compounds of fractions from Portulaca oleracea L. Food Chemistry, 133, 775-781.

Gould, A. W. (1977) Food Quality Assurance, pp. 93138. AVI Publ., Westport, CT.

Gülcin İ., Şat G., Beydemir Ş., Elmastaş M. and Küfrevioğlu Ö. İ. (2004) Comparison of antioxidant activity of clove (Eugenia caryophylataThunb) buds and lavender (Lavandulastoechs L.). Food Chemistry 87 393-400.

Hekmat S., Soltani H. and Reid, G. (2009) Growth and survival of Lactobacillus reuteri $\mathrm{RC}-14$ and Lactobacillus rhamnosus GR-1 in yogurt for Use as a functional food.Innovative Food Science and Emerging Technologies 10, (2) 293-296.

Helal A and Tagliazucchi D (2018) Impact of in-vitro gastro-pancreatic digestion on polyphenols and cinnamaldehyde bioaccessibility and antioxidant activity in stirred cinnamon-fortified yogurt. $L W T-$ Food Science and Technology, 89, 164-170.

ISO 21527-1. (2008) Microbiology of food and animal feeding stuffs -- Horizontal method for theenumeration of yeasts and moulds - Part 1: Colony count technique in products with wateractivity greater than 0.95 .

ISO 4832. (2006) Microbiology of food and animal feeding stuffs -- Horizontal method for the 374 enumeration of coliforms -- Colony-count technique.

Kailasapathy, K. (2006) Survival of free and encapsulated probiotic bacteria and their effect on the sensory properties of yogurt. LWT - Food Science and Technology, 39, 1221-1227.

Kilara A. and Chandan R. C. (2013) Greek-style yogurt and related products.In Manufacturing Yogurt and Fermented Milks, $2^{\text {nd }}$ edn, pp 297-318. Chandan R C, Kilara A, eds. Wiley-Blackwell, West Sussex, UK.

Kycia K., Chlebowska- Śmigiel A., Gniewosz M. and Sokó E. (2018) Effect of pullulan on the physicochemical properties of yoghurt. Journal of Dairy Technology, 71 (1) 64-70.

Lamothe S., Azimy, N., Bazinet, L., Couillard, C. and Britten, M. (2014) Interaction of green tea polyphenols with dairy matrices in a simulated gastrointestinal environment. Food and Function, 5 (10), 2621-2631.

Li B. B., Smith B. and Hossain M. M. (2006) Extraction of phenolics from citrus peles: I. solvent extraction method. Separation and Purification Technology, 48, 182-188.

Masoodi M. H., Ahmad B., Mir, S. R., Zargar, B.A. and Tabasum, N. (2011) Portulaca oleracea L. A Review. Journal of Pharmacy Research, 4 (9) 3044-3048.

McCue, P. and Shetty, K. (2005) Phenolic antioxidant mobilization during yogurt production from soymilk using Kefir cultures. Process Biochemistry 40, 1791-1797.

Mercan, E., Sert, D., Karakavuk, E. and Akin, N. (2018) Effect of different levels of grapeseed (Vitis vinifera) oil addition on physicochemical, microbiological and sensory properties of set-type yoghurt. International Journal of Dairy Technology, 71 (1) $34-43$.

Michael, M., Phebus, R. K. and Schmidt, K. A. (2015) Plant extract enhances the viability of Lactobacillus delbrueckii subsp. bulgaricus and Lactobacillus acidophilus in probiotic nonfat yogurt. Journal of Food Science and Nutrition, 3, 48-55.

Nguyen, H. T., Afsar, S. and Day, L. (2018) Differences in the microstructure and rheological properties of low-fat yoghurts from goat, sheep and cow milk. Food Research International, 108, 423-429.

Nguyen, P. T. M., Kravchuk, O., Bhandari B. and Prakash S. (2017) Effect of different hydrocolloids on texture, rheology, tribology and sensory perception of texture and mouthfeel of low-fat potset yoghurt. Food Hydrocolloids, 72 90-104.

Nsabimana, C., Jiang, B. and Kossah, R. (2005) Manufacturing, properties and shelf life of labneh: a review. International Journal of Dairy Technology, 58 (3) 129-137.

Oyaizu, M. (1986) Studies on products of browning reaction: antioxidative activities of products of browning reaction prepared from glucosamine. Japan Journal of Nutrition, 44, 307-315.

Öztürk H. İ., Aydın S., Sözeri D., Demirci T., Sert D. and Akin N. (2018) Fortification of settype yoghurts with Elaeagnus angustifolia L. flours: Effects on physicochemical, textural, and microstructural characteristics. LWT - Food Science

Egypt. J. Food. 47, No.1 (2019) 
and Technology, 90, 620-626.

Papadimitriou C. G., Mastrojiannaki A. V., Silva A. V., Gomes A. M., Malcata F.X. and Alichanidis E. (2007) Identification of peptides in traditional and probiotic sheep milk yoghurt with angiotensin I-converting enzyme (ACE)-inhibitory activity. Food Chemistry, 105, 647-656.

Peng, S.H., Dai1,W., Yu1, H., Wang, Y., Wang, X. and Sun, S. (2014) Antibacterial Activity of Aqueous and Ethanolic Extracts of Portulaca Oleracea L and Taraxacum mongolicum Against Pathogenic Bacteria of Cow Mastitis. International Journal of Applied Research in Veterinary Medicine, 12 (3) 210-213.

Pimentel T. C., Madrona G. S., Garcia S. and Prudencio S. H. (2015) Probiotic viability, physicochemical characteristics and acceptability during refrigerated storage of clarified apple juice supplemented with Lactobacillus paracasei ssp. paracasei and oligofructose in different package type. LWT-Food Science and Technology, 63, 415-422.

Ramchandran, L. and Shah, N. P. (2009) Effect of exopolysaccharides on the proteolytic and angiotensin-I converting enzyme-inhibitory activities and textural and rheological properties of low-fat yogurt during refrigerated storage. Journal of Dairy Science, 92 (3) 895-906.

Ramos L. R., Santos J. S., Daguer H., Valese A. C., Cruz A. G., Granato D. (2017) Analytical optimization of a phenolic-rich herbal extract and supplementation in fermented milk containing sweet potato pulp. Food Chemistry, 221 950-958.

Rashed A. N., Afifi F. U. and Disi A. M. (2003) Simple evaluation of the wound healing activity of a crude extract of Portulaca oleracea L. (growing in Jordan) in Musmusculus JVI-1, Journal of Ethnopharmacology, 88 131-136.

ŞanlıdereAloğlu, H. and Oner, Z. (2011) Determination of antioxidant activity of bioactive peptide fractions obtained from yoghurt. Journal of Dairy Science, 94 (11) 5305-5314.

Sarker S. D., Nahar, L. and Kumarasamy Y. (2007) Microtitreplatebased antibacterial assay incorporating resazurin as an indicator of cell growth, and its application in the in vitro antibacterial screening of phytochemicals. Methods, 42, 321-324.

SAS (2004) SAS Procedure Guide "Version 6.12 Ed." SAS Institute Inc., Cary.
Shah, N. P. (2015) Novel dairy probiotic products.In Advances in Probiotic Technology, pp 338-355. Foerst P. and Santivarangkna C. (Ed.) Science Publishers, CRC Press, Taylor andFrancis Group, Boca Raton, FL, USA.

Shah, N. P. and Champagne, C. (2016) Cultured milk and yogurt. In Dairy Processing and Quality Assurance, pp. 235-265. Chandan R. C., Kilara A. and Shah N. P., (Ed.). Blackwell Publishing, Ames, Iowa, USA.

Shetty K., Clydesdale F. and Vattem D. (2005) Clonal screening and sprout based bioprocessing of phenolic phytochemicals for functional foods. In Food Biotechnology, 2 ${ }^{\text {nd }}$ ed, pp. 603. Shetty K., Paliyath G., Pometto A. and Levin R. E. (Ed.). New York: CRC/ Taylor and Francis.

Shori, A.B. and Baba A. S. (2013) Antioxidant activity and inhibition of key enzymes linked to type-2 diabetes and hypertension by Azadirachtaindicayogurt. Journal of Saudi Chemical Society. 17. 295-301.

Tamime, A. Y. and Robinson, R. K. (2007) Traditional and recent developments in yoghurt production and related products. In Yoghurt: Science and Technology, $3^{\text {rd }}$ ed. Tamime A. Y., Robinson R. K. (Ed.), (pp. 348-367). Boca Raton, FL: CRC Press.

Thompson J. L., Lopetcharat K. and Drake M. A. (2007) Preferences for commercial strawberry drinkable yogurts among African American, Caucasian, and Hispanic consumers in the United States. Journal of Dairy Science, 90 (11), 4974-4987.

Tseng, A. and Zhao. Y. (2013) Wine grape pomace as antioxidant dietary fibre for enhancing nutritional value and improving storability of yogurt and salad dressing. Food Chemistry, 138, 356-365.

Uddin M K, Juraimi A, Ali M E and Ismail M R (2012) Evaluation of Antioxidant Properties and Mineral Composition of Purslane (Portulaca oleracea L.) at Different Growth Stages. International Journal of Molecular Sciences, 13, 10257-10267.

Udu-Ibiam, O. E., Ogbu O., Nworie O., Ibiam U.A., Agah M. V., Nnachi A. U., Ogbu K. I. and Chukwu O. S. (2014) Antimicrobial Activities of Some Selected Edible Mushrooms and Spices Against Clinical Isolates from Federal University Teaching Hospital Abakaliki (FETHA), Ebonyi State, Nigeria. International Journal of Scientific and Technology Research, 3 (5) 251-255. 
Uduwerella G., Chandrapala J. and Vasiljevic T. (2017) Minimising generation of acid whey during Greek yoghurt manufacturing. Journal of Dairy Research. 84. 346-354.

Vital A. C. P., Goto P.A., Hanai L. N., Gomes-daCosta S. M., Abreu Filho B.A., Nakamura C. V. and Matumoto-Pintro P. T. (2015) Microbiological, functional and rheological properties of low fat yogurt supplemented with Pleurotus ostreatus aqueous extract. LWT - Food Science and Technology, 64, 1028-1035.

Wenzel G. E., Fontana J. D. and Correa J. B. C. (1990) The viscous mucilage from the weed Portulaca oleracea L. Applied Biochemistry and Biotechnology, 24, 341-353.

Williams, E. B., Hooper, B., Spiro, A. and Stanner. S. (2015) The contribution of yogurt to nutrient intakes across the life course. Nutrition Bulletin, 40, 9-32.

Yang, Z., Liu, C., Xiang, L. and Zheng, Y. (2009) Phenolic alkaloids as a new class of antioxidants in Portulacaoleracea. Phytotherapy Research 23 (7)
$1032-1035$.

Yazici , I., Turkan, I., Sekmen, A. H. and Demiral, T. (2007) Salinity tolerance of purslane (Portulaca oleracea L.) is achieved by enhanced antioxidative system, lower level of lipid peroxidation and proline accumulation. Environmental and Experimental Botany, 61, 49-57.

Youssef, K.M. and Mokhtar, S. M. (2014) Effect of Drying Methods on the Antioxidant Capacity, Color and Phytochemicals of Portulaca oleracea L. Leaves. Nutrition and Food Science, 4, 322-328.

YouGuo, C., ZongJia, S. and XiaoPing, C. (2009) Evaluation of free radicals scavenging and immunity-modulatory activities of Purslane polysaccharides. International Journal of Biological Macromolecules, 45, 448-452.

Zhu Y., Wang C., Jia S., Wang B., Zhou K., Chen, S., Yang Y. and Liu S. (2018) Purification, characterization and antioxidant activity of the exopolysaccharide from Weissella cibaria SJ14 isolated from Sichuan paocai. International Journal of Biological Macromolecules, 115, 820-828.

\section{تأثير مستخلص الرجلة كعامل مضاد للأكسدة والميكروبات علي جودة وفترة صلاحية الزبادي اليوناني

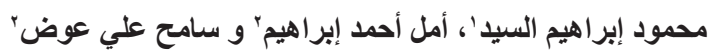

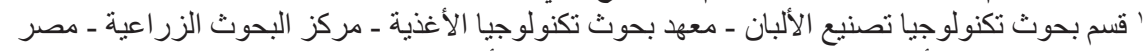

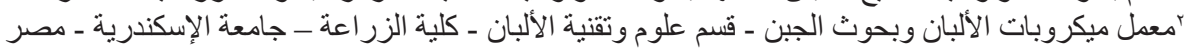

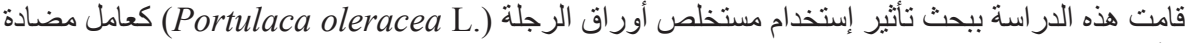

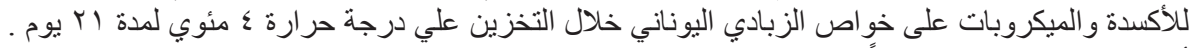

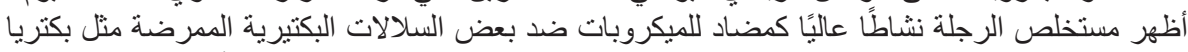

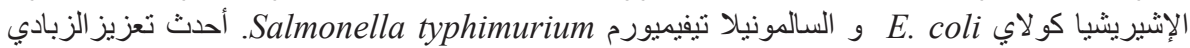

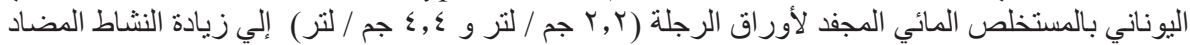

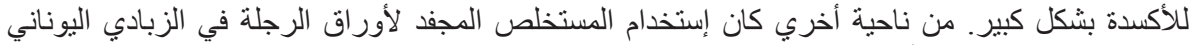

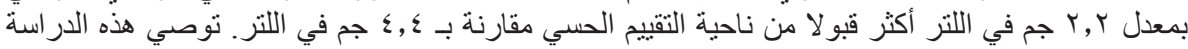

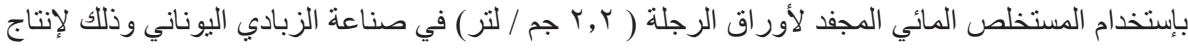

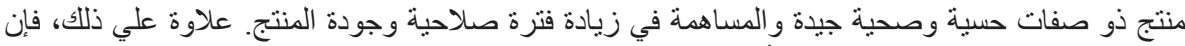

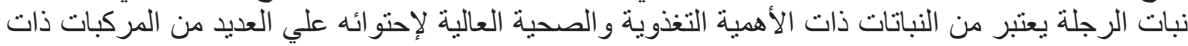

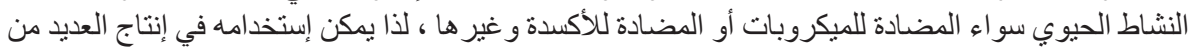

الأغذية الوظيفية.
} 